уДК 577.21:577.214.622 + 616-006.484.04

V.V. DMITRENKO ${ }^{1}$, V.M. KAVSAN ${ }^{1}$, O.I. BOYKO ${ }^{1}$, V.I. RYMAR ${ }^{1}$, A.A. STEPANENKO ${ }^{1}$, O.V. BALYNSKA ${ }^{1}$,

T.A. MALISHEVA ${ }^{2}$, V.D. ROZUMENKO ${ }^{2}$, Y.P. ZOZULYA ${ }^{2}$

${ }^{1}$ Institute of Molecular Biology and Genetics, Kyiv, Ukraine

${ }^{2}$ A.P. Romodanov Institute of Neurosurgery, Kyiv, Ukraine E-mail: dmitrenko@imbg.org.ua

\section{EXPRESSION OF GENES BELONGING TO THE IGF-SYSTEM IN GLIAL TUMORS}

Increased expression of the insulin-like growth factor (IGF) family members, IGF1, IGF2, their receptors and binding proteins, or combinations thereof has been documented in various malignancies including gliomas. The results of multiple investigations suggest that the IGFs can play a paracrine and/or autocrine role in promoting tumor growth in situ during tumor progression but that these roles may vary depending on the tissue of origin. Enhanced IGF1 expression was not found in glioblastomas and it was supposed that IGF1 participation in the development of glial tumors may be substituted by protein products of highly expressed other genes, also participating in PI3K and MAPK pathways. Increased expression of IGF-binding protein genes in brain tumors makes the picture even more complicated. As other binding proteins, IGFBPS regulate the activity of their ligands by prolonging their half-life. The discrepancies arising from conflicting evidence on the results obtained by different laboratories in human gliomas are discussed. Our data highlight the importance of viewing the IGF-related proteins as a complex multifactorial system and show that changes in the expression levels of any one component of the system, in a given malignancy, should be interpreted with caution. As IGF targeting for anticancer therapy is rapidly becoming clinical reality, an understanding of this complexity is very timely.

(C) V.V. DMITRENKO, V.M. KAVSAN, O.I. BOYKO, V.I. RYMAR, A.A. STEPANENKO, O.V. BALYNSKA, T.A. MALISHEVA, V.D. ROZUMENKO, Y.P. ZOZULYA, 2011
Introduction. In recent years, evidences have been appearing that the members of IGF system may be involved in cancer development. The antisense strategies, directed to the components of IGF-signaling, are the subject of many clinical trials. All three IGF receptors (IGF1R, INSR and IGF2R) are very well known targets for anti-cancer therapy. Increased expression of IGF1 receptor same as its ligands may stimulate PI $3 \mathrm{~K}$ and MAPK signaling cascades leading to cell proliferation [1-3].

However, the role of IGFs, IGF receptors and IGF-binding proteins (IGFBPs) in tumor development is poorly understood to this time. Increased levels of IGF1, IGF2 and their receptors have been found in different tumor types (reviewed in [4]), although the data about $I G F 1$ and $I G F 2$ gene expression in astrocytic gliomas are quite ambiguous. There are several publications reporting enhanced expression of these genes in anaplastic astrocytomas and glioblastomas on the RNA or protein levels [5-8]. For example, Sandberg et al. [5] analysed the expression of IGF genes by slot blot and Northern blot hybridization and found several fold increased $I G F 1$ and $I G F 2 \mathrm{mRNA}$ levels in one anaplastic astrocytoma and three glioblastoma specimens analyzed as compared to different regions of human adult normal brain. In other work, these authors demonstrated by immunohistochemistry the production of IGF1-like peptide in tumor cells in two of three anaplastic astrocytomas and in three of four glioblastomas examined [6]. In situ hybridization and immunocytochemistry also have localized a production of both IGF1 and IGF2 mRNA and protein in small number of astrocytoma samples analyzed that was accompanied by the co-expression of respective type-1 and type-2 IGF receptors [7]. Immunocytochemical analysis of 39 astrocytic tumors of WHO grades II-IV revealed tumor cells expressing IGF1 and IGF1R in all tumor grades (however, authors do not show how many of samples being under investigation were positive) [8].

On the other hand, the expression of $I G F 1$ and $I G F 2$ genes in astrocytic tumors was not found in other investigations. Thus, IGF2 mRNA was not detected by Northern analysis in 5 astrocytomas and 2 glioblastomas [9], and the expression of IGF1 was not found by Northern analysis in two investigated gliomas (ependymoma and glioblastoma) [10]. Earlier, we also could not find the significant change of IGF1 gene expression in glioblastoma by 
Serial Analysis of Gene Expression (SAGE) [11]. Such contradictory results could be explained by not enough big quantity of samples being under investigations. Nevertheless, IGF1 and IGF2 genes were not presented also in the lists of the genes with significant expression changes in the articles on integrative genome-wide analysis of 81 [12] and 460 glioblastoma samples [13].

Expression of insulin-like growth factor binding protein (IGFBP) genes in brain tumors makes the picture even more complicated. The IGFBP family consists of six high-affinity members (IGFBP1-IGFBP6) and four low-affinity proteins (IGFBP7-IGFBP10) which contain on the $\mathrm{NH}_{2}$-termini conserved «IGFBP motif» (GCGCCXXC), share significant structural homology with IGFBP1-IGFBP6, and able specifically bind IGFs, although with relatively low affinity [14]. As other binding proteins, IGFBPs regulate the activity of their ligands by prolonging their half-life. The biological actions of IGFs may be regulated by IGFBPs either negatively or positively, depending on the tissue type and the physiological or pathological status, some of the IGFBPs also act by a mechanism independent of IGFs. Elevation of the activity of IGF1 and IGF2 in the absence of the increasing of their genes expression may be a result of the enhancement of stability and lifetime due to the interaction with IGFBPs [15]. In addition to functioning in extracellular fluids as simple carrier proteins regulating circulating IGF turnover, transport, and distribution, the locally produced IGFBPs act as autocrine/paracrine regulators of IGF action [16].

Here, we analyze the expression of IGF system members including all ten IGFBP genes in glioblastoma by different methods to clarify their expression patterns in this tumor.

Materials and methods. SAGE Genie database (http://cgap.nci.nih.gov/SAGE) was used for the comparison of gene expression in glioblastoma and human normal brain by Digital Gene Expression Displayer (DGED) tool. Two pools of SAGElibraries (9 libraries of glioblastoma and 5 normal adult human brain libraries) were compared. Data, obtained by microarray analysis and available in Gene Expression Omnibus (GEO) site (http:// www.ncbi.nlm. nih.gov/geo), were used also for the comparison of these genes expression in glial tumors and normal brain. DataSet files were searched by keywords «glioblastoma», «astrocytoma», and «normal brain». A DataSet represents a collection of biologically- and statistically-comparable samples processed using the same platform. In order to measure expression levels from different DataSet files accurately, normalization by several housekeeping genes was required. Scripts, written in Perl were used for the analysis of these data.

Glioblastoma surgical specimens were classified on the basis of examination of hematoxylin and eosin stained sections according to World Health Organization (WHO) criteria [17]. Surgical specimens of histologically normal brain tissue adjacent to tumors were used as a source of normal adult human brain RNA and protein. All patients were being treated at the hospital of A.P. Romodanov Institute of Neurosurgery (Kyiv, Ukraine). The study protocol was approved by the human ethics review committees of both institutions and a signed consent forms from patients were obtained. The tissue samples were stored at $-70{ }^{\circ} \mathrm{C}$ until analysis. RNA was extracted from frozen samples as described in our previous articles $[11,18]$.

Equal amounts of total cellular RNA ( $5 \mu \mathrm{g}$ each for $20 \mu \mathrm{l}$ mixture) were transcribed into cDNA with an oligo (dT)/random hexamer primers and Revert Aid M-MuLV reverse transcriptase $(« \mathrm{Fer}-$ mentas», Lithuania). Each semi-quantitative RTPCR was performed in $25 \mu \mathrm{l}$ reaction mixture containing cDNA synthesized on 50 ng of RNA ( $2 \mu 1$ of 10-fold diluted cDNA), 2U Dream Taq Green DNA polymerase ((«Fermentas», Lithuania), manufacturer's buffer, $0.2 \mathrm{mM}$ dNTPs, and $10 \mu \mathrm{M}$ gene-specific primers (Table 1). Thermal cycling parameters were: initial denaturing step at $95^{\circ} \mathrm{C}$ for $2 \mathrm{~min}$, followed by $27-35$ cycles of denaturation at $95{ }^{\circ} \mathrm{C}$ for $30 \mathrm{sec}$, annealing at $56{ }^{\circ} \mathrm{C}$ for $30 \mathrm{sec}$, synthesis at $72{ }^{\circ} \mathrm{C}$ for $30 \mathrm{sec}$, and final extension incubation at $72{ }^{\circ} \mathrm{C}$ for $7 \mathrm{~min}$. The number of cycles was chosen so that the PCR product amplification rate was in the linear phase. Amplified products were electrophoresed in a $1.5 \%$ agarose gel. Densitometric analysis of PCR product bands was carried out by using the Scion Image 1.62c program. Relative expression levels of examined genes were estimated by normalization to the expression level of control gene, $\beta$-actin $(A C T B)$. Data obtained with $A C T B$ were used for calculation of $\mathrm{P}$-value of gene expression changes 
in glioblastoma by unpaired t-test assuming unequal variance.

Real-time PCR was performed with the iCycler iQ5 (BIO-RAD, USA). Reaction mixture (20 $\mu \mathrm{l})$ contained $2 \mu \mathrm{l}$ cDNA (quantity equivalent to synthesized on $50 \mathrm{ng}$ of total RNA), $10 \mu$ Maxima $^{\mathrm{TM}}$ SYBR Green qPCR Master Mix («Fermentas») and 10 pmole of each IGF1, IGF2 and IGF1R gene-specific primer (Table 1). The amplification procedure of target genes was as follows: initial denaturing step at $95^{\circ} \mathrm{C}$ for $10 \mathrm{~min}$, followed by 40 cycles of denaturation at $95^{\circ} \mathrm{C}$ for $15 \mathrm{sec}$, annealing at $56{ }^{\circ} \mathrm{C}$ for $15 \mathrm{sec}$ and extension at $72{ }^{\circ} \mathrm{C}$ for $15 \mathrm{sec}$. Melting curve analysis was performed to confirm amplification of single bands. Reaction efficiency was calculated by $\mathrm{R}$ package named qpcR package [19]. Gene expression values (relative mRNA levels) were calculated based on the modified $\triangle \triangle \mathrm{Cq}$ method [20] as ratio of efficiency raised to power $\mathrm{Ct}$ of analyzed gene to efficiency increased to power $\mathrm{Ct}$ of reference gene $(A C T B)$.

Results. Serial Analysis of Gene Expression (SAGE) revealed a very low level of $I G F 1$ gene expression in glioblastoma. Thus, tag TTTGATTAAT corresponding to three known long IGF1 transcripts $(7370$ bases variant $1 \mathrm{mRNA}, \mathrm{Ac}$.No NM_001111283; 7204 bases variant 2 mRNA, Ac.No NM_001111284, and 7321 bases variant 4 mRNA, Ac̄.No NM_000618) was found as only one tag per 101053 tags in one (SAGE_Brain glioblastoma_B_R20) of nine adult glioblastoma

Primers used in this work for the analysis of gene expression

\begin{tabular}{|c|c|c|c|}
\hline Gene name & Primer sequences & Cycle number & PCR product size \\
\hline$I G F-I$ & $\begin{array}{l}\text { For GTCCTCCTCGCATCTCTTC } \\
\text { Rev ACATCTCCAGCCTCCTTAG }\end{array}$ & 32 & 242 \\
\hline$I G F-I I$ & $\begin{array}{l}\text { For ACACCCTCCAGTTCGTCT } \\
\text { Rev ACTGCTTCCAGGTGTCATA T }\end{array}$ & 35 & 249 \\
\hline$I G F-I R$ & $\begin{array}{l}\text { For ACAGAGAACCCCAAGACTGAGG } \\
\text { Rev TGATGTTGTAGGTGTCTGCGGC }\end{array}$ & 32 & 247 \\
\hline$I G F B P 1$ & $\begin{array}{l}\text { For CGGAGATAACTGAGGAGGA } \\
\text { Rev CACTGTCTGCTG TGATAAAATC }\end{array}$ & 32 & 271 \\
\hline$I G F B P 2$ & $\begin{array}{l}\text { For CTCAAGTCGGGTATGAAGG } \\
\text { Rev GAGTAGAGGTGCTCCAGA }\end{array}$ & 32 & 224 \\
\hline IGFBP3 & $\begin{array}{l}\text { For GCACAGATACCCAGAACT } \\
\text { Rev CCATACTTATCCAC A CACCA }\end{array}$ & 29 & 226 \\
\hline IGFBP4 & $\begin{array}{l}\text { For ACCTCTACATCATCCCCAT } \\
\text { Rev TCAGACTCAGACTCCAC T }\end{array}$ & 29 & 284 \\
\hline IGFBP5 & $\begin{array}{l}\text { For GACCGCAAAGGATTCTACAA } \\
\text { Rev ACTGAAAGTCCCCGTCAA }\end{array}$ & 29 & 130 \\
\hline IGFBP6 & $\begin{array}{l}\text { For GCAACTCCAGACTGAGGTC } \\
\text { Rev CTCGGTTTTTTGTTGAGTGATG }\end{array}$ & 32 & 353 \\
\hline IGFBP7 & $\begin{array}{l}\text { For CCATGACTACTTTTAACCATGCAG } \\
\text { Rev GGTGTACTTGAGCTGTGAGGTC }\end{array}$ & 29 & 366 \\
\hline$I G F B P 8$ & $\begin{array}{l}\text { For GGCTTACCGACTGGAAGAC } \\
\text { Rev GATAGGCTTGGAGATTTTGGG }\end{array}$ & 25 & 259 \\
\hline$I G F B P 9$ & $\begin{array}{l}\text { For CTGTGGTATGGGGTTCTC } \\
\text { Rev TGGATGGTTTTGGTATTGTG }\end{array}$ & 32 & 273 \\
\hline IGFBP10 & $\begin{array}{l}\text { For GCTCCCTGTTTTTGGAATG } \\
\text { Rev CATTTCTTGCCCTTTTTCAG }\end{array}$ & 29 & 231 \\
\hline$A C T B$ & $\begin{array}{l}\text { For AACTACCTTCACATCCATCA } \\
\text { Rev GTACATACTCCTGCTTGCT }\end{array}$ & 27 & 262 \\
\hline
\end{tabular}


Characteristics of DataSet files from Gene Expression Omnibus (GEO) repository used for the evaluation of gene expession changes in glioblastoma

\begin{tabular}{|c|c|c|c|}
\hline File name & Microarray platform & Authors/Reference & Short description of the experiments \\
\hline GDS1975 & $\begin{array}{l}\text { GPL96 } \\
\text { [HG-U133A] } \\
\text { Affymetrix Human } \\
\text { Genome U133A Array }\end{array}$ & $\begin{array}{l}\text { Freije et al., } 2004 \\
\text { [21] }\end{array}$ & $\begin{array}{l}\text { Large-scale gene expression analysis using the Affymetrix HG } \\
\text { U133 oligonucleotide arrays on } 85 \text { diffuse infiltrating gliomas of } \\
\text { all histologic types to assess whether a gene expression-based, } \\
\text { histology-independent classifier is predictive of survival and to } \\
\text { determine whether gene expression signatures provide insight } \\
\text { into the biology of gliomas }\end{array}$ \\
\hline GDS1815 & $\begin{array}{l}\text { GPL96 } \\
\text { [HG-U133A] } \\
\text { Affymetrix Human } \\
\text { Genome U133A Array }\end{array}$ & $\begin{array}{l}\text { Phillips et al., } \\
2006 \\
{[22]}\end{array}$ & $\begin{array}{l}77 \text { primary high-grade astrocytomas and } 23 \text { matched recur- } \\
\text { rences were profiled to identify changes in gene expression that } \\
\text { relate to both survival and disease progression. Samples include } \\
\text { WHO grade III and IV astrocytomas with a wide range of sur- } \\
\text { vival times. Novel prognostic subclasses of high-grade astrocy- } \\
\text { toma are identified and discovered to resemble stages in neuro- } \\
\text { genesis }\end{array}$ \\
\hline GDS1096 & $\begin{array}{l}\text { GPL96 } \\
\text { [HG-U133A] } \\
\text { Affymetrix Human } \\
\text { Genome U133A Array }\end{array}$ & $\begin{array}{l}\text { Ge et al., } 2005 \\
{[23]}\end{array}$ & $\begin{array}{l}\text { Genome-wide expression profiling of } 36 \text { types of normal human } \\
\text { tissues. Each RNA tissue sample pooled from several donors. } \\
2503 \text { tissue-specific genes were identified. Results provide base- } \\
\text { lines for interpretation of gene expression profiles of cancers. }\end{array}$ \\
\hline GDS1962 & $\begin{array}{l}\text { GPL570 } \\
\text { [HG-U133_Plus_2] } \\
\text { Affymetrix Human } \\
\text { Genome U133 Plus } 2.0 \\
\text { Array }\end{array}$ & $\begin{array}{l}\text { Sun et al., } 2006 \\
{[24]}\end{array}$ & $\begin{array}{l}\text { mRNA expression data were collected from patients with brain } \\
\text { tumor to improve diagnostic of gliomas on molecular level. } 23 \\
\text { samples from epilepsy patients were used as non-tumor samples. } \\
157 \text { tumor samples included } 26 \text { astrocytomas, } 50 \text { oligoden- } \\
\text { drogliomas and } 81 \text { glioblastomas }\end{array}$ \\
\hline GDS3069 & $\begin{array}{l}\text { GPL96 } \\
\text { [HG-U133A] } \\
\text { Affymetrix Human } \\
\text { Genome U133A Array }\end{array}$ & $\begin{array}{l}\text { Liu et al., } 2007 \\
{[25]}\end{array}$ & $\begin{array}{l}\text { Analysis of } 12 \text { primary brain tumor biopsies with some variation } \\
\text { in their histological diagnoses. These results, together with those } \\
\text { obtained from miRNA profiling by real-time PCR, provide } \\
\text { insight into the relationship between endogenous fluctuations in } \\
\text { miRNA and mRNA expression levels }\end{array}$ \\
\hline GDS596 & $\begin{array}{l}\text { GPL96 } \\
\text { [HG-U133A] } \\
\text { Affymetrix Human } \\
\text { Genome U133A Array }\end{array}$ & $\begin{array}{l}\text { Su et al., } 2004 \\
{[26]}\end{array}$ & $\begin{array}{l}\text { Designed custom arrays that interrogate the expression of the } \\
\text { vast majority of protein-encoding human and mouse genes were } \\
\text { used to profile a panel of } 79 \text { human and } 61 \text { mouse tissues. The } \\
\text { resulting data set provides the expression patterns for thousands } \\
\text { of predicted genes, as well as known and poorly characterized } \\
\text { genes, from mice and humans }\end{array}$ \\
\hline
\end{tabular}

SAGE-libraries from Cancer Genome Anatomy Project database. No one glioblastoma SAGElibrary contains the tag CCCAAGACCC corresponding to the shortest IGF1 transcript (949 bases variant 3 mRNA, Ac No NM_001111285).

Gene Expression Omnibus (GEO) Datasets (http://www.ncbi.nlm.nih.gov/gds) were used to increase the statistical significance of SAGE results. Obtained files represented the experimental data on gene expression according to microarray analysis. Altogether, there were found six DataSet files which contained data concerning gene expression in
225 glioblastoma and 71 normal brain samples (Table 2). To compare data from experiments with different microarray platforms, we used a normalization method proposed for real-time PCR by dividing expression level of every gene on geometric average of three housekeeping genes, $A C T B$, glyceraldehyde 3-phosphate dehydrogenase $(G A P D H)$ and TATA-box binding protein (TBP) [27].

In GEO repository, IGF1 gene set consists of three different probes corresponded to three nucleotide sequences in GeneBank (AU144912, M29644 and M37484) and represented different 
regions of IGF1 mRNA. Although the results were little bit different for each probe (Fig. 1), the average IGF1 gene expression level was even 1,5-fold lower in glioblastoma than in anaplastic astrocytoma or human normal brain with $\mathrm{P}<0.05$ (the significance of differences was calculated using unpaired two-tailed t-test and assuming unequal variance (Table 3). Analysis of each DataSet file for each $I G F 1$ probe also did not reveal significant differences in $I G F 1$ expression between glioblastoma, anaplastic astrocytoma and normal brain as for example it is demonstrated for GDS1962 (GEO DataSet record 1962) file in Fig. 2. Realtime PCR showed also slightly decreased $I G F 1$ expression level (Fig. 3).

As it concerns IGF2 gene, SAGE revealed about 30 -fold increased average expression level in glioblastoma as compared to adult normal brain. However, this increasing was not statistically significant $(\mathrm{P}=0,293)$ due to the very high expression levels in two of nine glioblastoma samples, much more than the sample population median level. In GEO repository, IGF2 gene set also consists of three different probes corresponding to nucleotide sequences in GeneBank: M17863, NM_000612 and X07868. In spite of some variations between different probes, the results show mainly that in average the expression level of $I G F-I I$ gene in glioblastoma is increased slightly as compared to anaplastic astrocytoma or normal brain (Fig. 4) and 1,6-fold increasing of average $I G F-I I$ expression in glioblastoma as compared to human normal brain is statistically significant (Table 3). Analysis of individual DataSet files for each IGF2 probe showed that glioblastomas can be divided on two subgroups: one group has low expression level of IGF2 gene just like normal brain samples, but other group was characterized by significantly increased expression of IGF2 gene (Fig. 5, $a$ ). This division could be seen more distinctly if individual samples of 81 glioblastomas and 23 normal brains, analyzed in GDS1962 file, to arrange according to IGF2 expression level in descending order: approximately one quarter of glioblastoma samples has increased IGF2 expression level while other three quarters of glioblastoma samples have low expression level (Fig. 5, $b$ ). These microarray data are in a good concordance with results obtained by SAGE and were supported by real-time (Fig. 3) and semi-quantitative RT-PCR (Fig. 6).

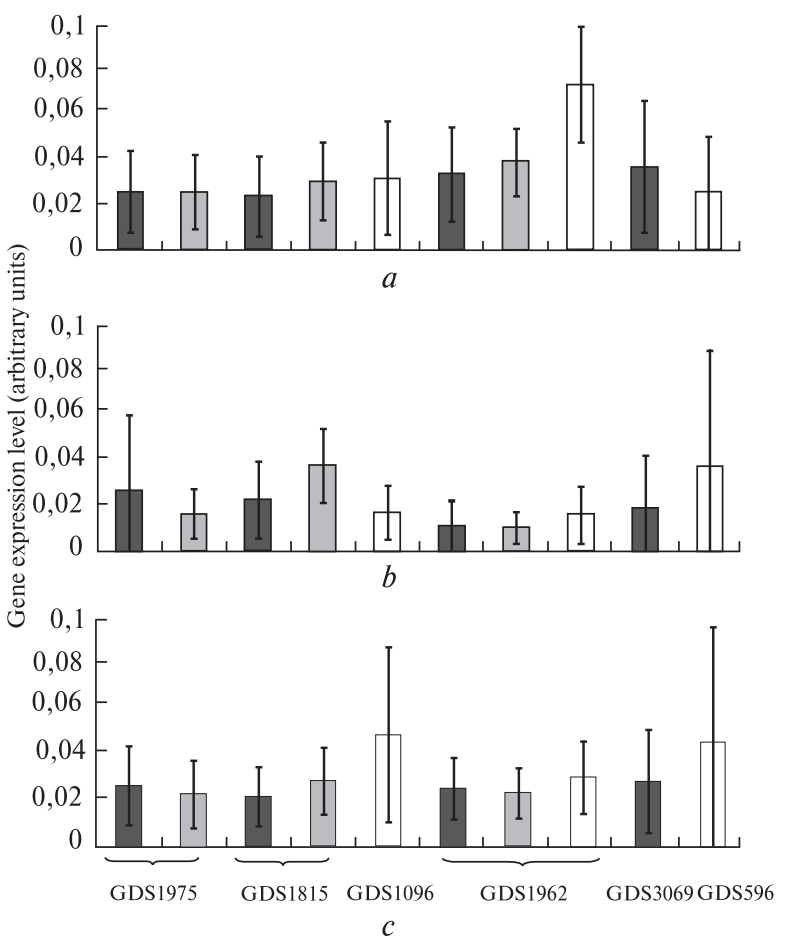

Fig. 1. Comparison of IGF1 relative expression levels in glioblastoma, anaplastic astrocytoma and human normal brain according to microarray analysis data from six DataSet files of GEO repository (indicated below the bars in diagram). Data are presented for three probe sets of IGF1 gene located on microarrays: AU14491 (a), M29644 (b) and M37484 (c). Samples of normal brain indicated by white bars, anaplastic astrocytomas - by grey bars, glioblastomas - by dark bars

IGF1 receptor is very well known target for anti-cancer therapy [28]. However, SAGE revealed only 1,4 -fold not statistically significant increasing of IGF1R expression $(\mathrm{P}=0,510)$ and microarray techniques showed even 1,2-fold $(P=0,046)$ decreasing of its expression in glioblastoma as compared to normal brain (Table 3). Real-time RT-PCR (Fig. 3) revealed 1,7-fold increasing of IGF1R expression, but the result was not statistically significant $(P=0,545)$. Thus, it can be concluded that IGF1R expression do not differ significantly in glial tumors and human normal brain. Expression of insulin receptor (IR), which is used alternatively by IGF2 [29], was decreased in 1,5fold in glioblastoma according to SAGE and microarray results. At the same time, the expression of IGF2R gene was increased in glioblastoma as compared to normal brain according to SAGE 


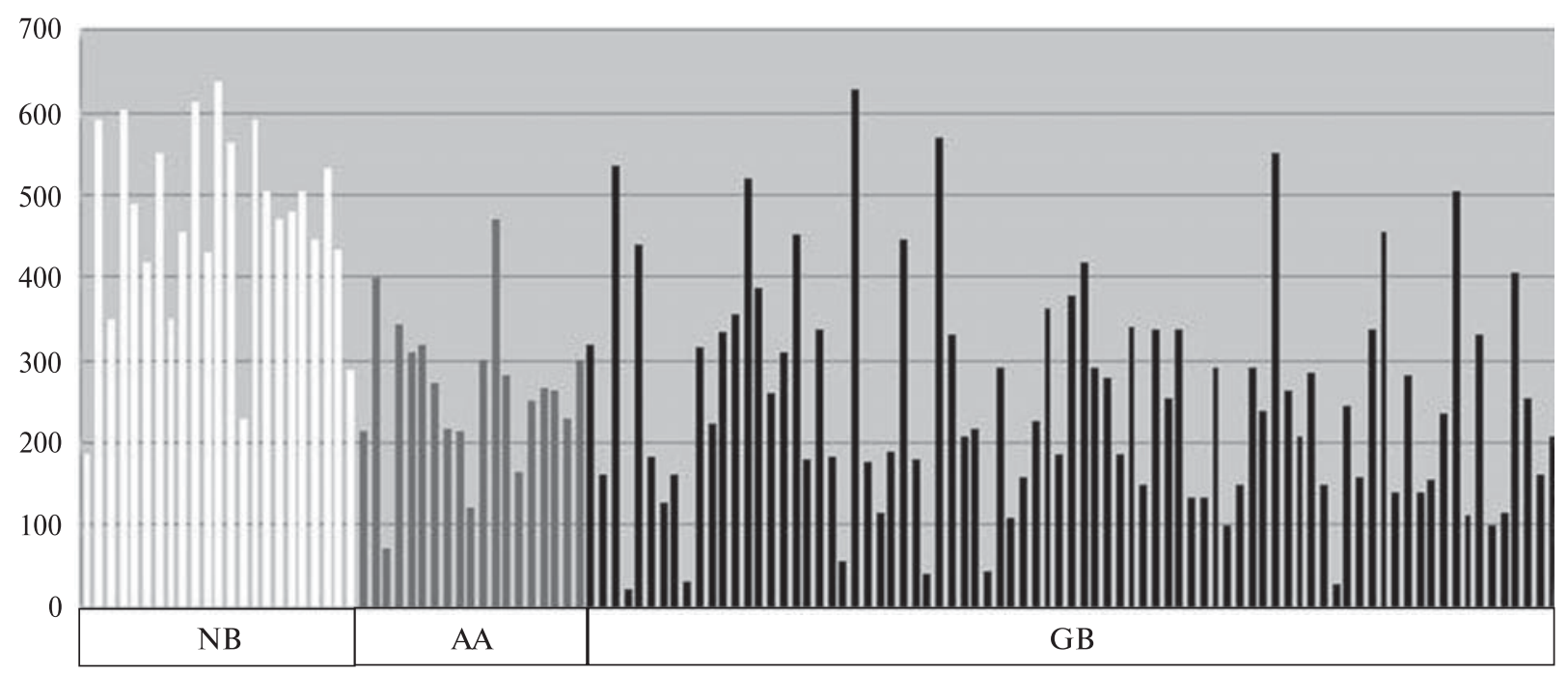

Fig. 2. IGF1 expression in individual samples of glioblastoma, anaplastic astrocytoma and normal brain. Expression profile for IGF1 gene (GeneBank: AU144912) obtained on the basis of the experimental data from DataSet record GDS1962 of GEO repository, submitted by Sun et al. [24]

(3,3-fold, $\mathrm{P}=0,053)$ and microarray analysis data (1,9-fold, $\mathrm{P}<0,001)$ (Table 3).

Comparison of IGFBP genes expression in glioblastoma and normal brain by SAGE revealed increased expression of all genes in glioblastoma except IGFBP1 (Table 3). More than 3-fold upregulation of IGFBP2, IGFBP3, IGFBP4, IGFBP5, and IGFBP7 genes in glioblastoma was statistically significant $(\mathrm{P}<0,05)$ and confirmed by data of microarray analysis, which showed statistically significant increased expression levels also for $I G F B P 8$ and IGFBP 10 in addition to these five genes. Decreased expression of remained three genes (IGFBP 1, IGFBP6 and IGFBP9) in glioblas-

Table 3

Changes of the expression of IGF-system genes in glioblastoma according to three methods

\begin{tabular}{|c|c|c|c|c|c|c|c|c|c|c|c|c|}
\hline \multirow{3}{*}{ Gene name } & \multicolumn{4}{|c|}{ SAGE } & \multicolumn{4}{|c|}{ Microarrays } & \multicolumn{4}{|c|}{ RT-PCR } \\
\hline & \multicolumn{2}{|c|}{ Average } & \multirow{2}{*}{$\mathrm{GB} / \mathrm{NB}$} & \multirow{2}{*}{$P$} & \multicolumn{2}{|c|}{ Average } & \multirow{2}{*}{$\mathrm{GB} / \mathrm{NB}$} & \multirow{2}{*}{$P$} & \multicolumn{2}{|c|}{ Average } & \multirow{2}{*}{ GB/NB } & \multirow{2}{*}{$P$} \\
\hline & GB & NB & & & GB & NB & & & GB & NB & & \\
\hline$I G F 1$ & 0.1 & 0.0 & $\mathrm{NaN}$ & 0.347 & 2.4 & 3.7 & 0.7 & $<0.001$ & 1.07 & 1.14 & 0.94 & $<0.001$ \\
\hline$I G F 2$ & 66.4 & 11.2 & 5.9 & 0.363 & 11.4 & 7.0 & 1.6 & 0.033 & 0.65 & 0.19 & 3.36 & 0.052 \\
\hline$I G F 1 R$ & 3.1 & 2.2 & 1.4 & 0.510 & 6.3 & 7.6 & 0.8 & 0.046 & 0.88 & 0.83 & 1.06 & 0.006 \\
\hline$I G F 2 R$ & 9.7 & 3.0 & 3.3 & 0.053 & 10.6 & 5.6 & 1.9 & $<0.001$ & 1.24 & 1.31 & 0.95 & $<0.001$ \\
\hline$I R$ & 2.4 & 3.4 & 0.7 & 0.488 & 2.9 & 5.3 & 0.6 & $<0.001$ & 1.15 & 1.17 & 0.98 & $<0.001$ \\
\hline IGFBPI & 1.4 & 2.4 & 0.6 & 0.506 & 1.6 & 2.2 & 0.7 & 0.058 & 1.17 & 0.62 & 1.88 & 0.008 \\
\hline$I G F B P 2$ & 34.3 & 5.6 & 6.1 & 0.023 & 87.3 & 5.4 & 16.3 & $<0.001$ & 2.00 & 0.77 & 2.58 & $<0.001$ \\
\hline IGFBP3 & 26.8 & 7.2 & 3.7 & 0.039 & 47.9 & 8.4 & 5.7 & $<0.001$ & 1.32 & 0.77 & 1.72 & 0.001 \\
\hline$I G F B P 4$ & 19.2 & 0.8 & 24.0 & 0.020 & 13.7 & 8.2 & 1.7 & $<0.001$ & 1.18 & 1.02 & 1.16 & $<0.001$ \\
\hline IGFBP5 & 165.6 & 26.0 & 6.4 & 0.032 & 27.1 & 9.9 & 2.7 & $<0.001$ & 1.73 & 0.64 & 2.71 & 0.072 \\
\hline IGFBP6 & 13.4 & 8.8 & 1.5 & 0.389 & 8.5 & 22.1 & 0.4 & 0.004 & 1.14 & 1.20 & 0.95 & $<0.001$ \\
\hline$I G F B P 7$ & 269.8 & 10.2 & 26.5 & 0.014 & 90.2 & 27.5 & 3.3 & $<0.001$ & 0.95 & 0.64 & 1.48 & 0.003 \\
\hline$I G F B P 8$ & 106.3 & 10.2 & 10.4 & 0.215 & 24.8 & 13.1 & 1.9 & $<0.001$ & 0.89 & 0.52 & 1.72 & 0.002 \\
\hline IGFBP9 & 0.6 & 0.0 & $\mathrm{NaN}$ & 0.247 & 4.4 & 10.6 & 0.4 & $<0.001$ & 1.45 & 1.60 & 0.90 & $<0.001$ \\
\hline IGFBP10 & 37.6 & 6.6 & 5.7 & 0.103 & 27.1 & 13.5 & 2.0 & $<0.001$ & 1.30 & 0.41 & 3.20 & 0.001 \\
\hline
\end{tabular}

Note. GB - glioblastoma, NB - normal brain. P-value below the chosen threshold $\mathrm{P}<0.05$ indicated in bold. 


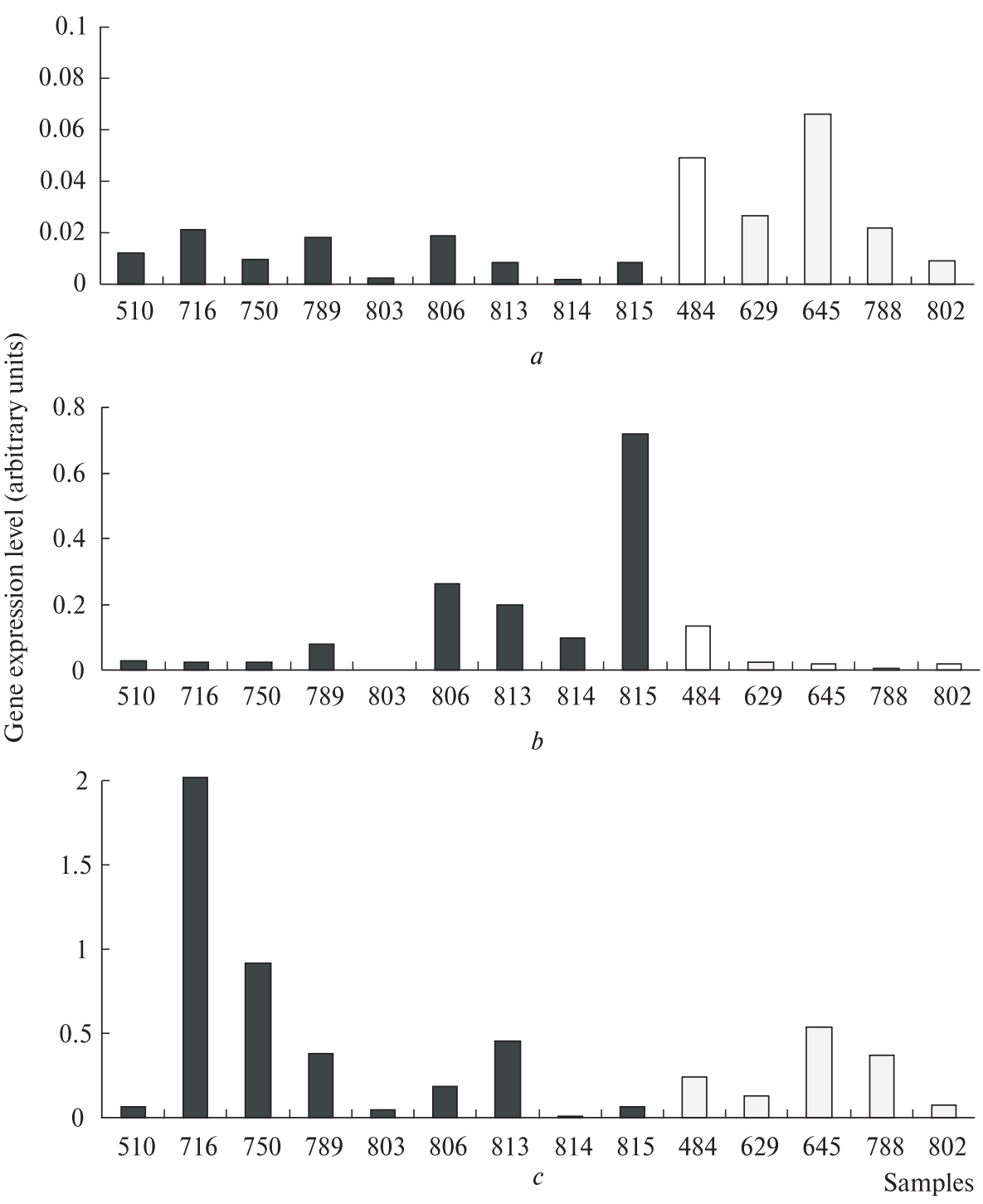

Fig. 3. Analysis of $\operatorname{IGF1}(a), \operatorname{IGF2}(b)$ and $\operatorname{IGF1R}(c)$ genes expression in glioblastoma and human normal brain by realtyme RT-PCR. Samples of normal brain indicated by white bars, glioblastomas - by dark bars

toma according to the results of microarray analysis in general were not in contradiction with SAGE results which showed some statistically nonsignificant decrease of the expression for IGFBPI or increase of the expression for IGFBP6 and IGFBP9 (Table 3).

Results of the IGFBP genes expression analysis by RT-PCR were in a quite good concordance with SAGE and microarray data. Semi-quantitative RT-PCR confirmed statistically significant increased expression of IGFBP2, IGFBP3, IGFBP4, $I G F B P 7, I G F B P 8$, and IGFBP10 genes in glioblas- toma (Fig. 6). Expression of IGFBP5 was increased too, although $\mathrm{P}=0,072$. $\mathrm{RT}-\mathrm{PCR}$ revealed also increased expression of IGFBP1 gene in glioblastoma and this 1,88-fold increase was statistically significant (Table 3). Unlike RT-PCR, SAGE and microarray analysis results showed not statistically significant decrease of $I G F B P 1$ expression level in glioblastoma. Expression of IGFBP6 and IGFBP9 genes was not changed significantly in glioblastoma according to the results of RT-PCR and this in general does not contradict to SAGE and microarray analysis, as mentioned above (Table 3 ). 

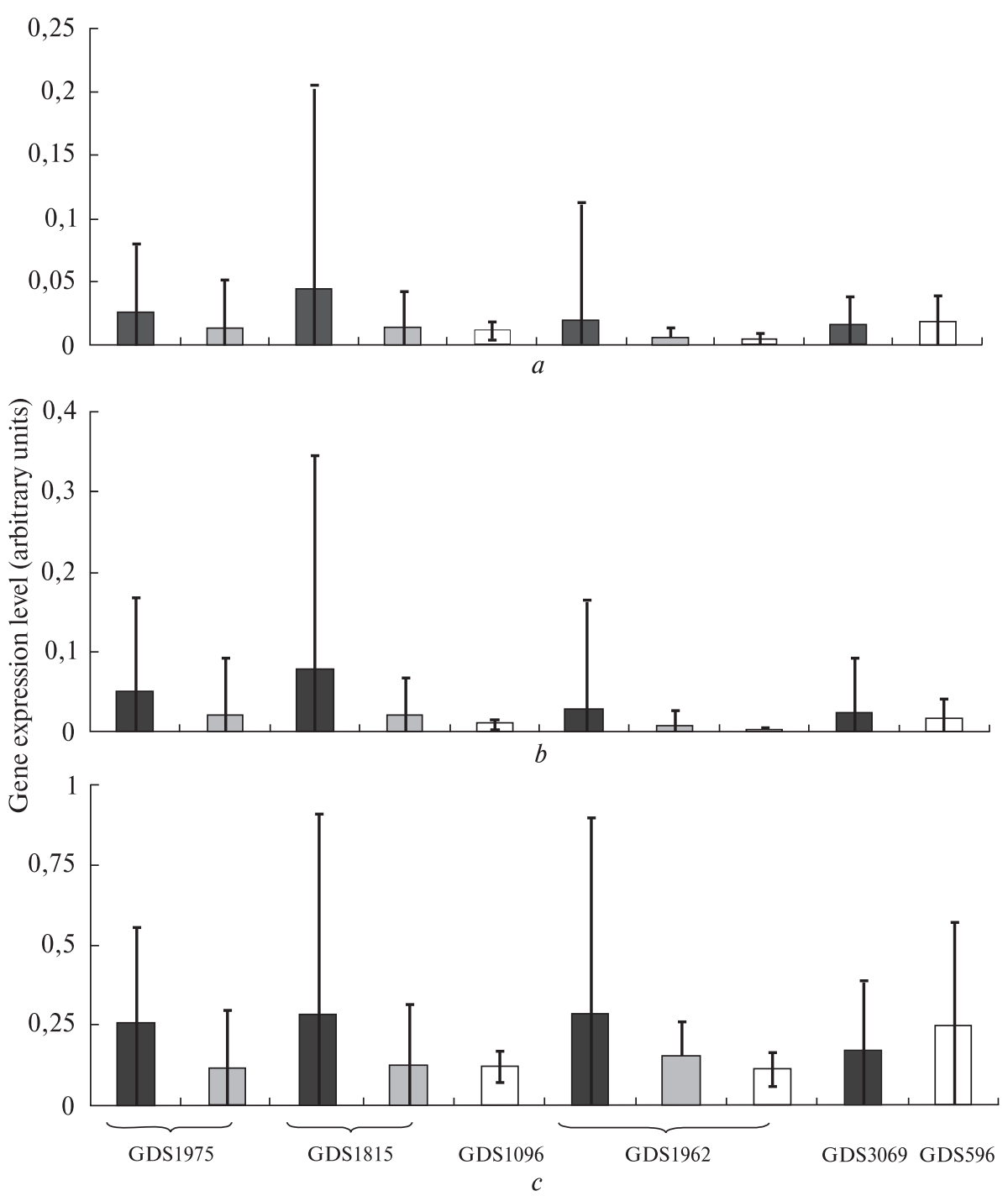

Fig. 4. Comparison of the relative expression levels of $I G F 2$ gene in glioblastoma, anaplastic astrocytoma and human normal brain according to microarray analysis data from six DataSet files of GEO repository (are indicated below the bars in diagram). Data are presented for three probe sets of IGF2 gene located on microarrays: M17863 (a), NM_000612 (b) and X07868 (c). Samples of normal brain indicated by white bars, anaplastic astrocytomas - by grey bars, glioblastomas - by dark bars

So, the expression of seven IGFBP genes (IGFBP2, IGFBP3, IGFBP4, IGFBP5, IGFBP7, $I G F B P 8$, and $I G F B P 10$ ) was increased in glioblastomas according to three methods used for the analysis. The results for IGFBP6 and IGFBP9 genes differ slightly for three methods, but there were no contrast differences between these results. It is necessary to note that gene expression differences found by microarray analysis were more statistically significant: p-values were below the chosen threshold $\mathrm{P}<0.05$ for all genes analysed except
IGFBP1. This may be explained by larger sample numbers in both glioblastoma and normal brain groups analysed by this method as compared to SAGE or RT-PCR.

Discussion. The central role that the IGF system plays in initiating and promoting tumor progression makes it an attractive target for cancer therapy. Various strategies have been used to target components of this system in established animal and human tumor cell lines and in animal models of cancer; some of these strategies may be advanc- 


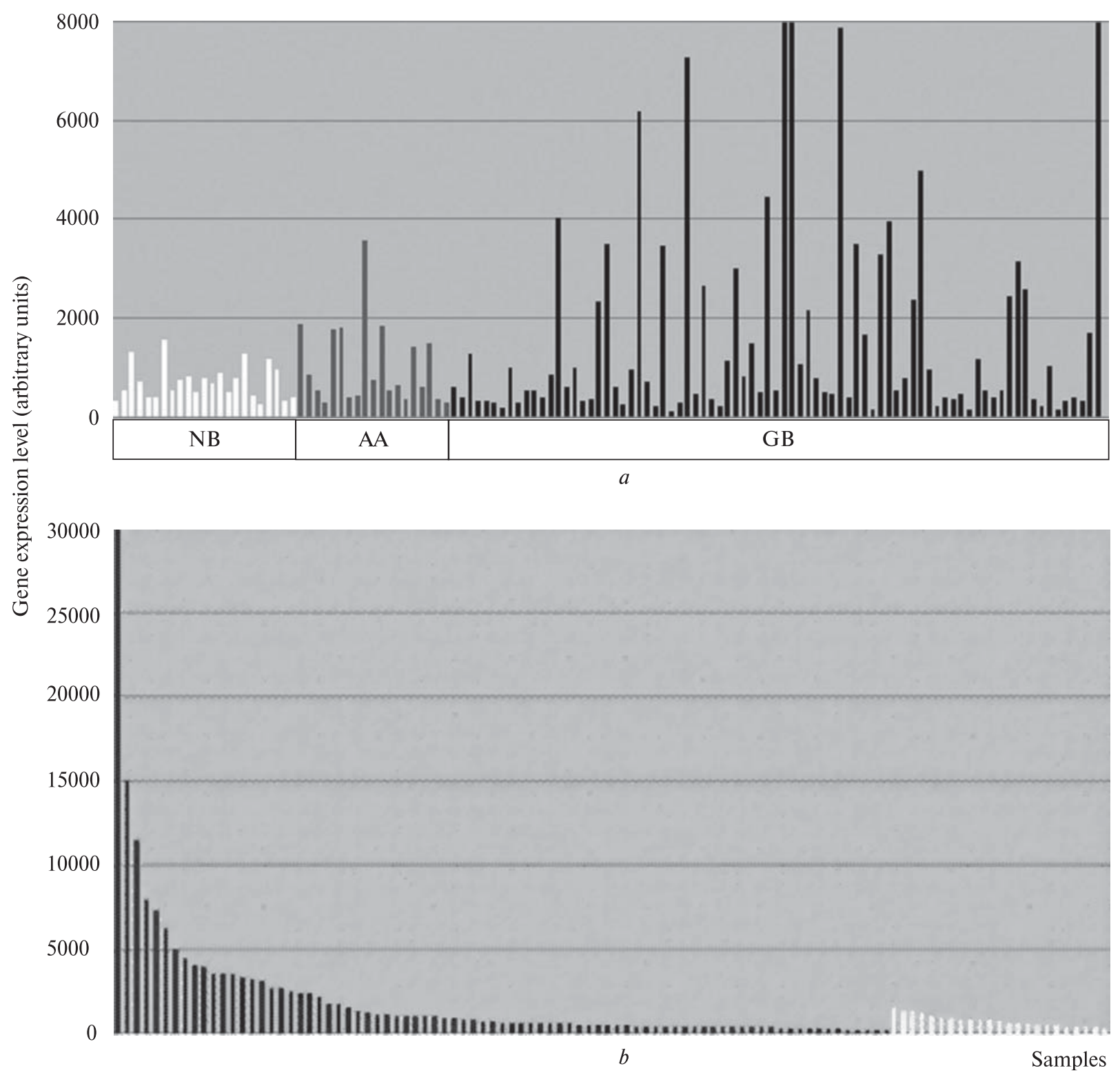

Fig. 5. IGF2 expression in individual samples of glioblastoma, anaplastic astrocytoma and normal brain: $a$ - expression profile for IGF2 gene (GeneBank: X07868) obtained on the basis of the experimental data from DataSet record GDS1962 of GEO repository, submitted by Sun et al. [24]; $b$ - comparison of IGF2 expression in glioblastoma and normal brain samples. Samples of normal brain indicated by white bars, glioblastomas - by dark bars

ing to clinical use. Among them IGF1 was targeted by different strategies including IGF1 peptide analogues [30], antisense oligonucleotides [31] and triple helix-expressing vectors [32].

Although increased expression of IGF1, IGF2, IGF1R or combinations thereof have been documented in various malignancies, these data show that while a correlation between IGF1/IGF2 expression levels and tumor progression could be consistently documented in some types of cancer (e.g. colorectal, hepatocellular and pancreatic carcinomas), no consistent correlation was seen in others (e.g. breast cancer) [4]. Taken as a whole, these studies suggest that the IGF1 role in a paracrine and/or autocrine promoting tumor growth may vary depending on the tissue of origin. 


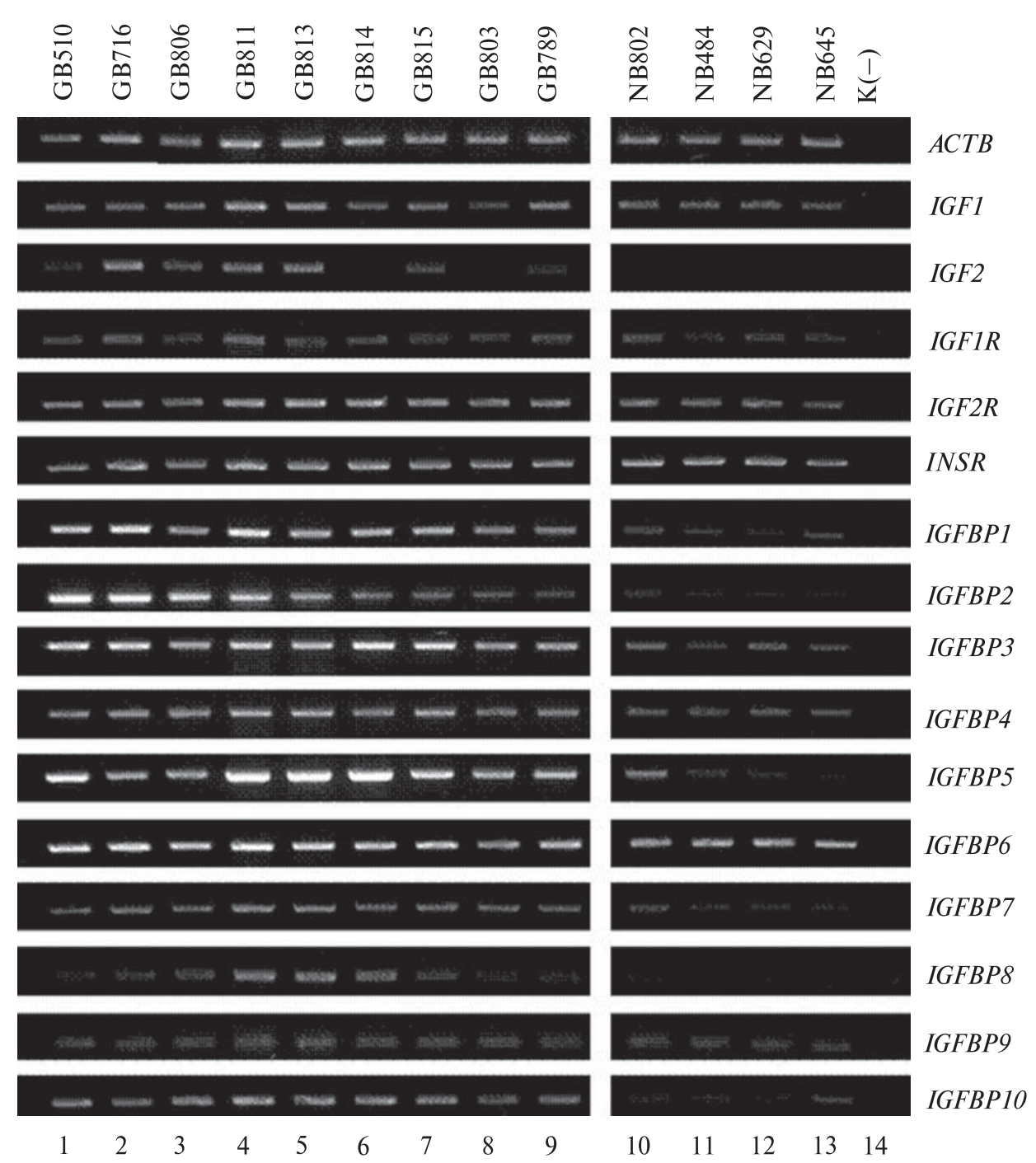

Fig. 6. Semi-quantitative PCR-analysis of IGF system genes expression in glioblastomas and normal brain. Control gene, $A C T B$, was used to determine relative expression level of analyzed genes in indivdual samples. Tissue and tumor types are indicated above each lane of the electrophoresis, numbers are the conditional numbers of RNA samples. GB - glioblastoma,

$\mathrm{NB}$ - human normal brain, $\mathrm{K}(-)-$ control reaction without cDNA

Moreover, in some cases, conflicting results were obtained in different studies that analysed the same types of malignant tumors (e.g. gliomas). The references on IGF1 gene expressions in glioblastoma are based on old papers, where authors used mostly slot blot hybridization or immunohistochemistry on comparably small numbers of clinical samples [5-10]. Immunohistochemical studies themselves are not very convin-cing: authors only mention the expression of $I G F 1$ in primary human astrocytomas [6] or write that IGFI mRNA can be seen in both astrocytoma and non malignant control human brain tissue [7]. The increased level of IGF1 expression was mostly at the margin of glioblastomas and in perivascular zone and so as it was explained by authors $[8,9]$, could not be seen when the total RNA from the whole tumor was taken for IGFI mRNA measurement.

On the other hand, the expression of IGF1 gene in astrocytic tumors was not found when we used SAGE or analysed data from the GEO repository. These data show that IGF1 gene is expressed at a 
low level in normal adult human brain and this level was not increased in glioblastoma. As it was mentioned above, other investigations also did not show the increased IGF1 gene expression in this tumor $[9,10]$. Taking into account quite big number of samples and different methods used in present investigation, the results of this study indicate that increasing of $I G F 1$ gene expression may be involved only in the formation of the limited part of astrocytic gliomas. Although the IGF1 was proposed as one of targets for glial tumor therapy and was supposed to become the alternative treatment for human glioblastoma [33], our results show why the anti-IGF1 treatment may not give positive results with gliomas, supposing that the development of these tumors is activated by some other way.

In contrast to $I G F 1$, the expression of IGF2 gene is up-regulated in glioblastoma although its expression level is relatively low as it was found previously in our work [34] as well as in other publications $[35,36]$. Microarray analysis data show clearly the existence of the separate group of the glioblastomas overexpressing $I G F 2$ gene. This is in agreement with the results of Soroceanu et al. [37] who found that among 165 primary high-grade astrocytomas, $13 \%$ of glioblastomas and $2 \%$ of anaplastic astrocytomas expressed IGF2 mRNA at the levels $>50$-fold the sample population median. Authors found that IGF2 can substitute for EGF to support the growth of glioblastoma-derived neurospheres and growth-promoting effects of IGF2 were mediated by the IGF1 receptor and phosphoinositide-3-kinase regulatory subunit 3 (PIK3R3), a regulatory subunit of PI3K.

Survey of published data revealed only two old publications in which the author reported about the fourfold increase of IGF2 receptor, but not IGF1 receptor [38] or 2- to 5-fold higher cellular concentration of IGF2 receptor than the amount of IGF1 receptor [39]. Thus, IGF1 participation in cellular signaling pathways of glioblastoma may be substituted by IGF2 which may also stimulate both main signaling pathways, regulated by the extracellular signal-regulated kinase (ERK1/2) and protein kinase B-mediated (AKT).

When viewed together, all studies concerning the role of IGFs and IGF1R expression levels per se as indicators of tumor stage or predicators of disease outcome defy simple generalization and may be highly tumor-type specific. However as dis- cussed above, the relevance of the IGF axis to cancer progression cannot be fully estimated by analysis of the expression levels of the IGF1R and its ligands only, because activation of the signaling pathway may occur through alternative mechanisms that bypass the requirement for receptor and/or ligand upregulation. For example, product of chitinase 3like 1 (CHI3L1, other names $H C g p-39$ or $Y K L-40)$ gene with significantly increased level in glioblastoma [40] may also stimulate ERK1/2- and AKTsignaling pathways in a concentration range similar to the effective dose of IGF1. Just as IGF1, it activates two signal cascades, regulated by ERK1/2 and AKT and associated with mitogenesis control [41].

Results of the analysis of IGFBP genes expression in glioblastoma, obtained with three methods, demonstrate up-regulation of the majority IGFBPS in this tumor. Increased expression of IGFBP2 [21, 42-48], IGFBP3 [44, 47, 49, 50], IGFBP4 [21, 49], IGFBP5 [44, 48-50], IGFBP6 [21, 44, 49], IGFBP7 [51], and IGFBP8 [44] genes in glioblastoma was reported previously in the studies using microarray analysis. It was shown that overexpression of IGFBP5 gene correlates with the histological grade of human diffuse glioma: $83 \%$ (58/70) of glioblastomas (WHO Grade IV) were immunopositive for IGFBP5, which was significantly higher than WHO Grade III gliomas $(41 \%, 41 / 101)$ or WHO Grade II gliomas $(18 \%, 13 / 72)(\mathrm{p}<0.001)$ [52]. Expression of IGFBPI to IGFBP6 was analysed by PCR in glioblastoma cell lines T98G, A172, $86 \mathrm{HG} 39$ and $\mathrm{U} 87 \mathrm{MG}$ and expression of IGFBP2IGFBP6 was found in all cell lines [36]. Higher content of IGFBP1 mRNA in primary gliomas was demonstrated only in one work [53]. Authors found by RT-PCR that expression level of IGFBPI gene did not depend on grade of tumor malignancy.

Produced in tumor cells IGFBPs may stabilize insulin-like growth factor (s), IGF1 and/or IGF2, and drive their activation in glial tumors. On the other hand, some of the IGFBPs inhibit IGF actions or may act by a mechanism independent of IGFs, as reviewed by Mohan and Baylink [16]. It was documented that IGFBP1 increased migration of Chinese hamster ovary cells and trophoblast cells and affected apoptosis of breast cancer cells independently of IGF1 by activating $\alpha 5 \beta 1$ integrinFAK-ILK-PI3-K-Akt signaling cascade [54].

Function of other inhibitory protein, IGFBP2, could be complex depending on the cell type and 
cellular microenvironment. As reviewed by Fukushima and Kataoka [55], IGFBP2 has been considered as an inhibitory factor of IGF actions, particularly of IGF2, but binding of the IGFBP2/IGF complex to cellular surface proteoglycan may result in concentration of IGFs on the cell surface thus enhancing their actions. Authors supposed, that since binding of IGFs by IGFBP2 has growth-and/or migration-inhibitory effects, other mechanisms must be taken into account if attempt to find the correlation between overexpression of IGFBP2 and malignant phenotypes of glioblastoma and proposed that IGFBP2 exerts influence on stimulation of cell proliferation and/or migration in an IGF-independent manner. Other study supported this suggestion and provided definitive evidence that IGFBP2 plays a key role in activation of the AKT pathway and collaborates with KRas or platelet derived growth factor B (PDGFB) in the development and progression of astrocytoma and oligodendroglioma [56].

IGFBP3 is known to block IGF action and inhibit cell growth. In addition, it possesses both growth-inhibitory and -potentiating effects on cells that are independent of IGF action and are mediated through specific IGFBP3 binding proteins/ receptors located at the cell membrane, cytosol, or nuclear compartments and in the extracellular matrix. Transferrin and type I alpha collagen were characterized as these IGFBP3 binding proteins [57, 58]. IGFBP3 was found among hypoxiainduced genes by the comparison of gene expression profiles of the U251 malignant glioma cell line under normoxic and hypoxic conditions, but the role of increased expression of IGFBP3 gene in glioma tumorigenesis is unclear [59].

It was revealed that IGFBP4, a negative modulator of IGF1, displayed IGF1-independent antiangiogenic effect on glioblastoma cells in response to their treatment by dibutyryl cyclic AMP (dBcAMP) [60].

IGFBP5 could also stimulate cell migration through interaction with cell surface heparin sulfate proteoglycans and to determine cell fates by regulating apoptotic molecules (bax, bcl-2) and activating p38 MAP kinase and ERK 1/2 signal transduction pathways [61].

IGFBP6 is a relatively specific inhibitor of IGF2 actions. Overexpression of IGFBP6 inhibits tumor growth by inducing apoptosis and recently
IGFBP6 was listed as a marker for cell senescence because it produces growth arrest with features of senescence but without the expression of cell differentiation markers [62].

IGFBP7 plays a negative role in the growth of cancer cells, including breast cancer, human prostate cancer, human cervical carcinoma (HeLa), murine embryonic carcinoma (P19), and osteosarcoma (Saos-2) cells [63]. Expression of IGFBP7 has been found to be up-regulated in human colorectal cancer and glioma cell lines and down-regulated in prostate and breast cancer cells. IGFBP7 is exclusively associated with laminin-stained glioblastoma vessels but was not observed in the vessels from nonmalignant brain [51]. IGFBP7 regulated glioma LN18 and LN443 cells proliferation and growth but not cell survival and promoted the migration of these cells through regulating the AKT (decreased phosphorylation) and ERK1/2 (enhanced phosphorylation) signal transductions [64].

IGFBP8(CTGF), IGFBP9(NOV) and IGFBP10 (CYR61) belong to the family of genes encoding CCN (cysteine-rich CYR61/CTGF/nephroblastoma-overexpressed gene) proteins which has been shown to play an important role in many processes, including proliferation, migration, adhesion, extracellular matrix regulation, angiogenesis, tumorigenesis, fibrosis, and implantation. CCN proteins share a modular structure and have in their $\mathrm{N}$-termini four conserved domains with sequence homologies to insulin-like growth factor binding proteins (IGFBPs) [65]. Expression of these three genes was analysed by real-time PCR in gliomas of different malignancy grades and normal human brain by Xie et al. [66]. Authors found enhanced expression of IGFBP 8 (CCN2) in 31 and IGFBP10 (CCN1) in 27 from 40 glioblastomas analysed, while only 7 glioblastomas had high levels of IGFBP9 (CCN3) mRNA. Significant correlation existed between IGFBP 8 and IGFBP10 mRNA levels with tumor grade and survival of glioblastoma patients, but statistical analysis showed no difference between the clinical and pathological features and expression level of IGFBP9 in gliomas. Results obtained in this work suggest that IGFBP8 and IGFBP10 may play some role in the progression of gliomas, but IGFBP9 is involved neither in their development nor progression. Furthermore, IGFBP9 had antiproliferative activity and suppressed the growth of glioma cells [67]. It was shown that IGFBP8 (CTGF) 
was associated with oncogenic activities and drug resistance in glioblastoma. Overexpression of IGFBP8 caused the U343 glioblastoma cells to survive for longer than 40 days in serum-free medium and resist antitumor drugs including tumor necrosis factor (TNF), TNF-related apoptosis-inducing ligand, VELCADE (bortezomib, proteasome inhibitor) and temozolomide [68]. Xie et al. [69] demonstrated that IGFBP10 acts as an oncogene through the integrin-linked kinase (ILK) to stimulate $\beta$-catenin-TCF/LEF and AKT signaling pathways. Authors showed that forced expression of IGFBP10 in U343 glioblastoma cells accelerated their growth in liquid culture, enhanced their anchorage-independent proliferation in soft agar, and significantly increased their ability to form tumors in nude mice.

As a summary, we have shown that IGF1 gene expression is increased only in few cases of glioblastoma but predominantly it is not higher that in normal brain. IGF1 participation in cellular signaling pathways of glioblastoma may be substituted by increasing expression of $I G F 2$ or $I G F 1 R$, which may also stimulate both main signaling pathways, regulated by ERK1/2 and AKT. Several other genes with significantly increased expression may also stimulate these pathways in glioblastoma. Up-regulated IGFBPs may activate IGF, even if the latters do not increase their expression leading to the anti-apoptotic consequences in glial tumors. On the other hand, increased production of some IGFBPs leads to enhance their IGFindependent effects which may play an important role in the development of gliomas.

Obtained results highlight the importance of viewing the IGF-related proteins as a complex multifactorial system and show that changes in the expression levels of any one component of the system, in a given malignancy, should be interpreted with caution. Similar to the experience with other biology-based therapies, effective targeting of the IGF system may require a customized approach, where tumor profiling guides the selection of the appropriate drugs. As targeting of the IGF-family members for anti-cancer therapy is rapidly becoming clinical reality, an understanding of this complexity is very timely.

This work was supported in part by National Academy of Sciences of Ukraine in frames of the pro- gram «Fundamental grounds of molecular and cell biotechnologies» and by Science and Technology Center in Ukraine, project 4688.

В.В. Дмитренко, В.М. Кавсан, О.И. Бойко, В.И. Рымарь, А.А. Степаненко, О.В. Балынская, Т.А. Малышева, В.Д. Розуменко, Ю.А. Зозуля

ЭКСПРЕССИЯ ГЕНОВ, ОТНОСЯЩИХСЯ K IGF-СИСТЕМЕ, В ГЛИАЛЬНЫХ ОПУХОЛЯХ

Повышенные уровни экспрессии отдельных членов семейства инсулиноподобных факторов роста (IGF) - IGF1 и IGF2, IGF-рецепторов, IGF-связывающих белков или их комбинации были обнаружены в различных новообразованиях, включая глиомы. Результаты множественных исследований свидетельствуют о том, что инсулиноподобные факторы роста могут стимулировать рост опухоли in situ аутокринным и/или паракринным способом, однако это действие может варьировать в зависимости от тканевого происхождения опухоли. Усиление экспрессии гена IGF1 не было найдено в глиобластомах и предполагается, что участие IGF1 в развитии глиальных опухолей может быть замещено белковыми продуктами экспрессирующихся на высоком уровне генов, также участвующими в сигнальных путях МАРК и РІ3К. Повышенный уровень экспрессии генов IGF-связывающих белков (IGFBP) в опухолях головного мозга делает картину еще более сложной. Как и другие связывающие белки, IGFBP регулируют активность своих лигандов, продлевая время их полужизни. В статье обсуждаются противоречивые результаты, описанные различными лабораториями для глиом. Полученные данные демонстрируют важность рассмотрения белков семейства инсулиноподобных факторов роста как сложную мультифункциональную систему и показывают, что изменения в уровне экспрессии любого компонента системы в упомянутой опухоли должны интерпретироваться с предосторожностью. В связи с тем, что выбор членов IGF-семейства в качестве мишени для противоопухолевой терапии быстро приобретает клиническую реальность, понимание сложности этой системы является весьма своевременным.

В.В. Дмитренко, В.М. Кавсан, О.І. Бойко,

B.I. Римар, О.А. Степаненко, О.В. Балинська, Т.А. Малишева, В.Д. Розуменко, Ю.П. Зозуля ЕКСПРЕСІЯ ГЕНІВ,

ЩО НАЛЕЖАТЬ ДО IGF-СИСТЕМИ, У ГЛІАЛЬНИХ ПУХЛИНАХ

Підвищений рівень експресії окремих членів родини інсуліноподібних факторів росту (IGF) - IGF1 та IGF2, IGF-рецепторів, IGF-зв'язуючих білків або їхньої комбінації був знайдений у різних новоутвореннях, включаючи гліоми. Результати множинних до- 
сліджень свідчать про те, що інсуліноподібні фактори росту можуть стимулювати ріст пухлини in situ аутокринним та/або паракринним способом, однак ця дія може варіювати в залежності від тканинного походження пухлини. Посилення експресії гена $I G F 1$ не було знайдено в гліобластомах і передбачається, що участь IGF1 у розвитку гліальних пухлин може бути замінена білковими продуктами генів, що експресуються на високому рівні, які також приймають участь у сигнальних шляхах MAPK та РІ3К. Підвищений рівень експресії генів IGF-зв'язуючих білків у пухлинах головного мозку робить картину ще більш складною. Як і інші зв'язуючі білки, IGF-зв'язуючі білки регулюють активність своїх лігандів, продовжуючи час їхнього півжиття. У статті обговорюються суперечливі результати, описані різними лабораторіями для гліом. Отримані дані демонструють важливість розгляду білків родини інсуліноподібних факторів росту як складну мультифункціональну систему і показують, що зміни рівня експресії будь-якого компонента системи у даній пухлині повинні інтерпретуватися із пересторогою. В зв'язку з тим, що вибір членів IGF-сімейства як мішені для протипухлинної терапії швидко набуває клінічної реальності, розуміння цієї системи є вельми своєчасним.

\section{REFERENCES}

1. Friedrichs N., K凶chler J., Endl E., Koch A., Czerwitzki J., Wurst P., Metzger D., Schulte J.H., Holst M.I., Heukamp L.C., Larsson O., Tanaka S., Kawai A., Wardelmann E., Buettner R., Pietsch T., Hartmann W. Insulin-like growth factor-1 receptor acts as a growth regulator in synovial sarcoma // J. Pathol. - 2008. - 216, № 4. - P. 428-439.

2. Eckstein N., Servan K., Hildebrandt B., P凶itz A., von Jonqui邓res G., Wolf-K冈mmeth S., Napierski I., Hamacher A., Kassack M.U., Budczies J., Beier M., Dietel M., RoyerPokora B., Denkert C., Royer H.D. Hyperactivation of the insulin-like growth factor receptor I signaling pathway is an essential event for cisplatin resistance of ovarian cancer cells // Cancer Res. - 2009. - 69, № 7. - P. 29963003.

3. Ma J., Sawai H., Matsuo Y., Ochi N., Yasuda A., Takahashi H., Wakasugi T., Funahashi H., Sato M., Takeyama H. IGF-1 mediates PTEN suppression and enhances cell invasion and proliferation via activation of the IGF-1/PI3K/Akt signaling pathway in pancreatic cancer cells // J. Surg. Res. - 2010. - 160, № 1. - P. 90101.

4. Samani A.A., Yakar S., LeRoith D., Brodt P. The role of the IGF system in cancer growth and metastasis: overview and recent insights // Endocr. Rev. - 2007. 28, № 1. - P. 20-47.

5. Sandberg A.C., Engberg C., Lake M., von Holst H., Sara $V . R$. The expression of insulin-like growth factor I and insulin-like growth factor II genes in the human fetal and adult brain and in glioma // Neurosci. Lett. 1988. - 93, № 1. - P. 114-119.

6. Sandberg-Nordqvist A.C., Stahlbom P.A., Reinecke M., Collins V.P., von Holst H., Sara V. Characterization of insulin-like growth factor 1 in human primary brain tumors // Cancer Res. - 1993. - 53, № 11. - P. 24752478.

7. Antoniades H.N., Galanopoulos T., Neville-Golden J., Maxwell M. Expression of insulin-like growth factors I and II and their receptor mRNAs in primary human astrocytomas and meningiomas; in vivo studies using in situ hybridization and immunocytochemistry // Int. J. Cancer. - 1992. - 50, № 2. - P. 215-222.

8. Hirano H., Lopes M.B., Laws Jr E.R., Asakura T., Goto M., Carpenter J.E., Karns L.R., Vanden Berg S.R. Insulinlike growth factor-1 content and pattern of expression correlates with histopathologic grade in diffusely infiltrating astrocytomas // Neuro Oncol. - 1999. - 1, № 2. - P. 109-119.

9. Lichtor T., Kurpakus M.A., Gurney M.E. Differential expression of insulin-like growth factor II in human meningiomas // Neurosurgery. - 1991. - 29, № 3. - P. 405409.

10. Glick R.P., Unterman T.G., Lacson R. Identification of insulin-like growth factor (IGF) and glucose transporter- 1 and -3 mRNA in CNS tumors // Regul. Pept. 1993. - 48, № 1/2. - P. 251-256.

11. Kavsan V., Shostak K., Dmitrenko V., Zozulya Y., Rozumenko $V$., Demotes-Mainard J. Characterization of genes with increased expression in human glioblastomas // Cytol. Genet. - 2005. - 39, № 1. - P. 37-49.

12. De Tayrac M., Etcheverry A., Aubry M., Saïkali S., Hamlat A., Quillien V., Le Treut A., Galibert M.D., Mosser $J$. Integrative genome-wide analysis reveals a robust genomic glioblastoma signature associated with copy number driving changes in gene expression // Genes Chromosomes Cancer. - 2009. - 48, № 1. - P. 55-68.

13. Verhaak R.G., Hoadley K.A., Purdom E., Wang V., Qi Y., Wilkerson M.D., Miller C.R., Ding L., Golub T., Mesirov J.P., Alexe G., Lawrence M., O'Kelly M., Tamayo P., Weir B.A., Gabriel S., Winckler W., Gupta S., Jakkula L., Feiler H.S., Hodgson J.G., James C.D., Sarkaria J.N., Brennan C., Kahn A., Spellman P.T., Wilson R.K., Speed T.P., Gray J.W., Meyerson M., Getz G., Perou C.M., Hayes D.N. Cancer Genome Atlas Research Network. Integrated genomic analysis identifies clinically relevant subtypes of glioblastoma characterized by abnormalities in PDGFRA, IDH1, EGFR, and NF1 // Cancer Cell. 2010. - 17, № 1. - P. 98-110.

14. Kim H.S., Nagalla S.R., Oh Y., Wilson E., Roberts C.T. Jr., Rosenfeld R.G. Identification of a family of low-affinity insulin-like growth factor binding proteins (IGFBPs): characterization of connective tissue growth factor as a member of the IGFBP superfamily // Proc. Natl. Acad. Sci. USA. - 1997. - 94, № 24. - P. 12981-12986. 


\section{Expression of genes belonging to the IGF-system in glial tumors}

15. Collett-Solberg P.F., Cohen P. Genetics, chemistry, and function of the IGF/IGFBP system // Endocrine. 2000. - 12, № 2. - P. 121-136.

16. Mohan S., Baylink D.J. IGF-binding proteins are multifunctional and act via IGF-dependent and -independent mechanisms // J. Endocrinol. - 2002. - 175, № 1. - P. 19-31.

17. Louis D.N., Ohgaki H., Wiestler O.D., Cavenee W.K., Burger P.C., Jouvet A., Scheithauer B.W., Kleihues P. The 2007 WHO Classification of Tumours of the Central Nervous System // Acta Neuropathol. - 2007. 114, № 2. - P. 97-109.

18. Kavsan V.M., Dmitrenko V.V., Shostak K.O., Bukreieva T.V., Vitak N.Y., Simirenko O.E., Malisheva T.A., Shamayev M.I., Rozumenko V.D., Zozulya Y.A. Comparison of microarray and SAGE techniques in gene expression analysis of human glioblastoma // Cytol. Genet. - 2007. - 41, № 1. - P. 36-55.

19. Ritz C., Spiess A.N. qpcR: an R package for sigmoidal model selection in quantitative real-time polymerase chain reaction analysis // Bioinformatics. - 2008. 24, № 13. - P. 1549-1551.

20. Livak K.J., Schmittgen T.D. Analysis of relative gene expression data using real-time quantitative PCR and the 2(-Delta Delta C (T)) method // Methods. - 2001. 25, № 4. - P. 402-408.

21. Freije W.A., Castro-Vargas F.E., Fang Z., Horvath S., Cloughesy T., Liau L.M., Mischel P.S., Nelson S.F. Gene expression profiling of gliomas strongly predicts survival // Cancer Res. - 2004. - 64, № 18. - P. 6503-6510.

22. Phillips H.S., Kharbanda S., Chen R., Forrest W.F., Soriano R.H., Wu T.D., Misra A., Nigro J.M., Colman H., Soroceanu L., Williams P.M., Modrusan Z., Feuerstein B.G., Aldape K. Molecular subclasses of high-grade glioma predict prognosis, delineate a pattern of disease progression, and resemble stages in neurogenesis // Cancer Cell. - 2006. - 9, № 3. - P. 157-173.

23. Ge X., Yamamoto S., Tsutsumi S., Midorikawa Y., Ihara S., Wang S.M., Aburatani H. Interpreting expression profiles of cancers by genome-wide survey of breadth of expression in normal tissues // Genomics. - 2005. 86, № 2. - P. 127-141.

24. Sun L., Hui A.M., Su Q., Vortmeyer A., Kotliarov Y., Pastorino S., Passaniti A., Menon J., Walling J., Bailey R., Rosenblum M., Mikkelsen T., Fine H.A. Neuronal and glioma-derived stem cell factor induces angiogenesis within the brain // Cancer Cell. - 2006. - 9, № 4. P. 287-300.

25. Liu T., Papagiannakopoulos T., Puskar K., Qi S., Santiago F., Clay W., Lao K., Lee Y., Nelson S.F., Kornblum H.I., Doyle F., Petzold L., Shraiman B., Kosik K.S. Detection of a microRNA signal in an in vivo expression set of mRNAs // PLoS One. - 2007. - 2, № 8. - P. e804.

26. Su A.I., Wiltshire T., Batalov S., Lapp H., Ching K.A., Block D., Zhang J., Soden R., Hayakawa M., Kreiman G.,
Cooke M.P., Walker J.R., Hogenesch J.B. A gene atlas of the mouse and human protein-encoding transcriptomes // Proc. Natl. Acad. Sci. USA. - 2004. - 101, № 16. - P. 6062-6067.

27. Vandesompele J., De Preter K., Pattyn F., Poppe B., Van Roy N., De Paepe A., Speleman F. Accurate normalization of real-time quantitative RT-PCR data by geometric averaging of multiple internal control genes // Genome Biol. - 2002. - 3, № 7. - P. RESEARCH0034.

28. Weroha S.J., Haluska $P$. IGF-1 receptor inhibitors in clinical trials - early lessons // J. Mammary Gland Biol. Neoplasia. - 2008. - 13, № 4. - P. 471-483.

29. Denley A., Wallace J.C., Cosgrove L.J., Forbes B.E. The insulin receptor isoform exon 11-(IR-A) in cancer and other diseases: a review // Horm. Metab. Res. - 2003. 35, № 11/12. - P. 778-785.

30. Pietrzkowski Z., Mulholland G., Gomella L., Jameson B.A., Wernicke D., Baserga R. Inhibition of growth of prostatic cancer cell lines by peptide analogues of insulin-like growth factor 1 // Cancer Res. - 1993. 53, № 5. - P. 1102-1106.

31. Rininsland F., Johnson T.R., Chernicky C.L., Schulze E., Burfeind P., Ilan J. Suppression of insulin-like growth factor type I receptor by a triple-helix strategy inhibits IGF-I transcription and tumorigenic potential of rat C6 glioblastoma cells // Proc. Natl. Acad. Sci. USA. - 1997. - 94, № 11. - P. 5854-5859.

32. Trojan J., Johnson T.R., Rudin S.D., Ilan J., Tykocinski M.L. Treatment and prevention of rat glioblastoma by immunogenic C6 cells expressing antisense insulin-like growth factor I RNA // Science. - 1993. - 259, № 5091. - P. 94-97.

33. Trojan J., Cloix J.F., Ardourel M.Y., Chatel M., Anthony $D . D$. Insulin-like growth factor type I biology and targeting in malignant gliomas // Neuroscience. - 2007. 145, № 3. - P. 795-811.

34. Dmitrenko V.V., Bukreeva T.V., Shostak K.O., Vitak N.Y., Pekarsky Y.A., Malisheva T.A., Shamayev M.I., Rozumenko V.D., Kondratyuk V.V., Zozulya Y.P., Kavsan V.M. Extraordinary high content of mRNA of IGF-II-associated protein in meningiomas // Ukr. Biochem. J. - 2007. - 79, № 1. - P. 55-61.

35. Nordqvist A.C., Peyrard M., Pettersson H., Mathiesen T., Collins V.P., Dumanski J.P., Schalling M. A high ratio of insulin-like growth factor II/insulin-like growth factor binding protein 2 messenger RNA as a marker for anaplasia in meningiomas // Cancer Res. - 1997. - 57, № 13. - P. 2611-2614.

36. Schlenska-Lange A., Kn囚pfer H., Lange T.J., Kiess W., $K n \bigotimes p f e r M$. Cell proliferation and migration in glioblastoma multiforme cell lines are influenced by insulinlike growth factor I in vitro // Anticancer Res. - 2008. 28, № 2a. - P. 1055-1060.

37. Soroceanu L., Kharbanda S., Chen R., Soriano R.H., Aldape K., Misra A., Zha J., Forrest W.F., Nigro J.M., 


\section{V.V. Dmitrenko, V.M. Kavsan, O.I. Boyko et al.}

Modrusan Z., Feuerstein B.G., Phillips H.S. Identification of IGF2 signaling through phosphoinositide-3-kinase regulatory subunit 3 as a growth-promoting axis in glioblastoma // Proc. Natl. Acad. Sci. USA. - 2007. 104, № 9. - P. 3466-3471.

38. Sara V.R., Prisell P., Sj內gren B., Persson L., Boethius J., Enberg $G$. Enhancement of insulin-like growth factor 2 receptors in glioblastoma // Cancer Lett. - 1986. 32, № 3. - P. 229-234.

39. Gammeltoft S., Ballotti R., Kowalski A., Westermark B., Van Obberghen E. Expression of two types of receptor for insulin-like growth factors in human malignant glioma // Cancer Res. - 1988. - 48, № 5. - P. $1233-$ 1237.

40. Shostak K., Labunskyy V., Dmitrenko V., Malisheva T., Shamayev M., Rozumenko V., Zozulya Y., Zehetner G., Kavsan $V$. HC gp-39 gene is upregulated in glioblastomas // Cancer Lett. - 2003. - 198, № 2. - P. $203-$ 210.

41. Recklies A.D., White C., Ling H. The chitinase 3-like protein human cartilage glycoprotein 39 (HC-gp39) stimulates proliferation of human connective-tissue cells and activates both extracellular signal-regulated kinase- and protein kinase B-mediated signalling pathways // Biochem. J. - 2002. - 365, Pt 1. - P. 119-126.

42. Fuller G.N., Rhee C.H., Hess K.R., Caskey L.S., Wang R., Bruner J.M., Yung W.K., Zhang W. Reactivation of insulin-like growth factor binding protein 2 expression in glioblastoma multiforme: a revelation by parallel gene expression profiling // Cancer Res. - 1999. - 59, № 17. - P. 4228-4232.

43. Zhang W., Wang H., Song S.W., Fuller G.N. Insulin-like growth factor binding protein 2: gene expression microarrays and the hypothesis-generation paradigm // Brain Pathol. - 2002. - 12, № 1. - P. 87-94.

44. Sallinen S.L., Sallinen P.K., Haapasalo H.K., Helin H.J., Helen P.T., Schraml P., Kallioniemi O.P., Kononen J. Identification of differentially expressed genes in human gliomas by DNA microarray and tissue chip techniques // Cancer Res. - 2000. - 60, № 23. - P. 6617-6622.

45. Rickman D.S., Bobek M.P., Misek D.E., Kuick R., Blaivas M., Kurnit D.M., Taylor J., Hanash S.M. Distinctive molecular profiles of high-grade and lowgrade gliomas based on oligonucleotide microarray analysis // Cancer Res. - 2001. - 61, № 18. - P. 68856891.

46. Kim S., Dougherty E.R., Shmulevich I., Hess K.R., Hamilton S.R., Trent J.M., Fuller G.N., Zhang W. Identification of combination gene sets for glioma classification. // Mol. Cancer Ther. - 2002. - 1, № 13. - P. 12291236.

47. Godard S., Getz G., Delorenzi M., Farmer P., Kobayashi H., Desbaillets I., Nozaki M., Diserens A.C., Hamou M.F., Dietrich P.Y., Regli L., Janzer R.C., Bucher P., Stupp R., De Tribolet N., Domany E., Hegi M.E. Classification of human astrocytic gliomas on the basis of gene expression: a correlated group of genes with angiogenic activity emerges as a strong predictor of subtypes // Cancer Res. - 2003. - 63, № 20. - P. 6613-6625.

48. Nigro J.M., Misra A., Zhang L., Smirnov I., Colman H., Griffin C., Ozburn N., Chen M., Pan E., Koul D., Yung W.K., Feuerstein B.G., Aldape K.D. Integrated arraycomparative genomic hybridization and expression array profiles identify clinically relevant molecular subtypes of glioblastoma // Cancer Res. - 2005. - 65, № 5. - P. 1678-1686.

49. Markert J.M., Fuller C.M., Gillespie G.Y., Bubien J.K., McLean L.A., Hong R.L., Lee K., Gullans S.R., Mapstone T.B., Benos D.J. Differential gene expression profiling in human brain tumors // Physiol. Genom. 2001. - 5, № 1. - P. 21-33.

50. Ljubimova J.Y., Lakhter A.J., Loksh A., Yong W.H., Riedinger M.S., Miner J.H., Sorokin L.M., Ljubimov $A . V$., Black $K$. Overexpression of alpha4 chain-containing laminins in human glial tumors identified by gene microarray analysis // Cancer Res. - 2001. - 61, № 14. - P. 5601-5610.

51. Pen A., Moreno M.J., Martin J., Stanimirovic D.B. Molecular markers of extracellular matrix remodeling in glioblastoma vessels: microarray study of laser-captured glioblastoma vessels // Glia. - 2007. - 55, № 6. P. 559-572.

52. Wang H., Wang H., Zhang W., Fuller G.N. Overexpression of IGFBP5, but not IGFBP3, correlates with the histologic grade of human diffuse glioma: a tissue microarray and immunohistochemical study // Technol. Cancer Res. Treat. - 2006. - 5, № 3. - P. 195-199.

53. Elmlinger M.W., Deininger M.H., Schuett B.S., Meyermann R., Duffner F., Grote E.H., Ranke M.B. In vivo expression of insulin-like growth factor-binding protein-2 in human gliomas increases with the tumor grade // Endocrinology. - 2001. - 142, № 4. - P. 16521658.

54. Wheatcroft S.B., Kearney M.T. IGF-dependent and IGFindependent actions of IGF-binding protein-1 and -2: implications for metabolic homeostasis // Trends in Endocrinol. Metab. - 2009. - 20, № 4. - P. 153-162.

55. Fukushima T., Kataoka H. Roles of insulin-like growth factor binding protein-2 (IGFBP-2) in glioblastoma // Anticancer Res. - 2007. - 27, № 6A. - P. 3685-3692.

56. Dunlap S.M., Celestino J., Wang H., Jiang R., Holland E.C., Fuller G.N., Zhang W. Insulin-like growth factor binding protein 2 promotes glioma development and progression // Proc. Natl. Acad. Sci. USA. - 2007. 104, № 28. - P. 11736-11741.

57. Weinzimer S.A., Gibson T.B., Collett-Solberg P.F., Khare A., Liu B., Cohen $P$. Transferrin is an insulin-like growth factor-binding protein-3 binding protein // J. Clin. Endocrinol. Metab. - 2001. - 86, № 4. - P. 18061813. 
58. Liu B., Weinzimer S.A., Gibson T.B., Mascarenhas D., Cohen $P$. Type Ialpha collagen is an IGFBP-3 binding protein // Growth Horm. IGF Res. - 2003. - 13, № 2/3. - P. 89-97.

59. Ragel B.T., Couldwell W.T., Gillespie D.L., Jensen R.L. Identification of hypoxia-induced genes in a malignant glioma cell line (U-251) by cDNA microarray analysis // Neurosurg. Rev. - 2007. - 30, № 3. - P. 181-187.

60. Moreno M.J., Ball M., Andrade M.F., McDermid A., Stanimirovic D.B. Insulin-like growth factor binding protein-4 (IGFBP-4) is a novel anti-angiogenic and anti-tumorigenic mediator secreted by dibutyryl cyclic AMP (dB-cAMP)-differentiated glioblastoma cells // Glia. - 2006. - 53, № 8. - P. 845-857.

61. Akkiprik M., Hu L., Sahin A., Hao X., Zhang W. The subcellular localization of IGFBP5 affects its cell growth and migration functions in breast cancer // BMC Cancer. - 2009. - 9. - P. 103

62. Iosef C., Vilk G., Gkourasas T., Lee K.J., Chen B.P., Fu P., Bach L.A., Lajoie G., Gupta M.B., Li S.S., Han V.K. Insulin-like growth factor binding protein-6 (IGFBP6) interacts with DNA-end binding protein $\mathrm{Ku} 80$ to regulate cell fate // Cell Signal. - 2010. - 22, № 7. P. 1033-1043.

63. Ruan W.J., Lin J., Xu E.P., Xu F.Y., Ma Y., Deng H., Huang Q., Lv B.J., Hu H., Cui J., Di M.J., Dong J.K., Lai $M . D$. IGFBP7 plays a potential tumor suppressor role against colorectal carcinogenesis with its expression associated with DNA hypomethylation of exon // J. Zhejiang Univ. Sci. B. - 2006. - 7, № 11. - P. 929-932.
64. Jiang W., Xiang C., Cazacu S., Brodie C., Mikkelsen T. Insulin-like growth factor binding protein 7 mediates glioma cell growth and migration // Neoplasia. - 2008. 10, № 12. - P. 1335-1342.

65. Chen C.C., Lau L.F. Functions and mechanisms of action of CCN matricellular proteins // Int. J. Biochem. Cell Biol. - 2009. - 41, № 4. - P. 771-783. 66. Xie D., Yin D., Wang H.J., Liu G.T., Elashoff R., Black K., Koeffler H.P. Levels of expression of CYR61 and CTGF are prognostic for tumor progression and survival of individuals with gliomas // Clin. Cancer Res. 2004. - 10, № 6. - P. 2072-2081.

67. Bleau A.M., Planque N., Lazar N., Zambelli D., Ori A., Quan T., Fisher G., Scotlandi K., Perbal B. Antiproliferative activity of $\mathrm{CCN} 3$ : involvement of the $\mathrm{C}$-terminal module and post-translational regulation // J. Cell Biochem. - 2007. - 101, № 6. - P. 1475-1491.

68. Yin D., Chen W., O'Kelly J., Lu D., Ham M., Doan N.B., Xie D., Wang C., Vadgama J., Said J.W., Black K.L., Koeffler H.P. Connective tissue growth factor associated with oncogenic activities and drug resistance in glioblastoma multiforme // Int. J. Cancer. - 2010. 127, № 10. - P. 2257-2267.

69. Xie D., Yin D., Tong X., O'Kelly J., Mori A., Miller C., Black K., Gui D., Said J.W., Koeffler H.P. Cyr61 is overexpressed in gliomas and involved in integrin-linked kinase-mediated Akt and beta-catenin-TCF/Lef signaling pathways // Cancer Res. - 2004. - 64, № 6. P. 1987-1996.

Received 17.03.11 